\title{
PERHITUNGAN FERTILITAS MENGGUNAKAN METODE ANAK KANDUNG: ANALISIS LANJUT DATA RISKESDAS 2013
}

\author{
Lely Indrawati, Dwi Hapsari, dan Olwin Nainggolan \\ Pusat Penelitian dan Pengembangan Upaya Kesehatan Masyarakat, Badan Litbangkes \\ Kemenkes Republik Indonesia
}

Korespondensi: Lely Indrawati (e-mail: lelyindra@gmail.com)

\begin{abstract}
Abstrak
Total Fertility Rate (TFR) merupakan jumlah rata-rata anak yang akan dilahirkan hidup oleh seorang perempuan pada akhir masa reproduksinya. TFR merupakan salah satu indikator ukuran kemajuan kesehatan, khususnya kesehatan ibu dalam satu negara. Oleh karenanya, target RPJMN 2015-2019 adalah menurunkan angka kelahiran. Penghitungan TFR yang tepat menggunakan metode tidak langsung, salah satunya adalah Own-Method Children (metode anak kandung). Populasi dalam penelitian ini adalah semua perempuan dan anak-anak yang tinggal bersama orang tuanya. Sampel dalam analisis perhitungan ini adalah wanita usia subur (WUS) umur 15 hingga 49 tahun dan anak balita yang tinggal bersama orang tuanya. Anak balita dalam perhitungan ini adalah anak kandung, sedangkan anak berstatus bukan anak kandung dilibatkan dalam penghitungan guna menambah jumlah anak yang berada dalam rumah tangga ibu. Hasil perhitungan menggunakan Riskesdas 2013 menunjukkan bahwa TFR di Indonesia lebih tinggi $(3,2)$ dibandingkan dengan hasil perhitungan dengan sumber data yang lain. Jika dilihat dari pola ASFR (Age Specific Fertility Rate), angka kelahiran tertinggi tercatat pada usia 20-24 kemudian usia 15-19. Implikasi pentingnya adalah fokus program keluarga berencana harus diberikan pada kelompok umur tersebut, salah satunya adalah dengan peningkatan usia kawin pertama.
\end{abstract}

Kata kunci: fertilitas, metode anak kandung, age specific fertility rate (ASFR)

\section{ASSESING FERITILITY RATE USING OWN-CHILDREN METHOD: FURTHER ANALYSIS OF RISKESDAS 2013}

\begin{abstract}
Total Fertility Rate (TFR) is the average number of children born alive by a number of women at the end of their reproductive period. TFR is one indicator of health development, especially maternal health in the country. Therefore, target of reducing the birth rate is still prioritized in RPJMN 2015-2019. Indirect method is more appropriate to calculate TFR, such as own-method children. Population of this study is women and their children in the same househoold with women of childbearing aged 15-49 years and children under five who live with their parents as sampling unit. Children under five in this analysis are the biological children while step children will be included in order to enhance the number children. The calculation based on 2013 Riskesdas (Riset Kesehatan Dasar) shows higher TFR compared to 2012 DHS (Demographic and Health Survey) which was 3.2 at national level. ASFR (Age Specific Fertility Rate) pattern shows highest fertility rate for age of 20-24, while it was second for age 15-19. The important implication is that family planning program has to concentrate on this age groups, such as by increasing age of the first marriage.
\end{abstract}

Keywords: fertility, own-children method, age specific fertility rate (ASFR) 


\section{Pendahuluan}

Pada Konferensi Tingkat Tinggi (KTT) Milenium Perserikatan Bangsa-Bangsa (PBB) September 2000, sebanyak 189 negara anggota PBB, termasuk Indonesia, sepakat untuk mengadopsi Deklarasi Milenium yang kemudian dijabarkan dalam kerangka praktis Tujuan Pembangunan Milenium (Millenium Developments Goals/MDGs). MDGs menempatkan pembangunan manusia sebagai fokus utama dengan tenggat waktu hingga 2015. MDGs juga merupakan komitmen nasional untuk lebih menyejahterakan masyarakat melalui pengurangan kemiskinan dan kelaparan, pendidikan, pemberdayaan perempuan, kesehatan, serta lingkungan.

MDGs memiliki delapan tujuan yang harus dilaksanakan oleh setiap negara yang mendeklarasikannya sebagai berikut. 1) Menanggulangi kemiskinan dan kelaparan, 2) mencapai pendidikan dasar untuk semua, serta 3) mendorong kesetaraan gender dan pemberdayaan perempuan. Kemudian 4) menurunkan angka kematian anak, 5) meningkatkan kesehatan ibu, 6) memerangi HIVIAIDS, malaria, dan penyakit menular lainnya, 7) memastikan kelestarian lingkungan hidup, serta 8) mengembangkan kemitraan global untuk pembangunan. Sementara itu, dari delapan tujuan MDGs tersebut, yang menjadi tanggung jawab Kementerian Kesehatan adalah tujuan 1, 4, 5, 6, dan 7. Setiap tujuan memiliki satu atau beberapa target beserta indikatornya (Depkes, 2011).

Upaya percepatan pencapaian target MDGs menjadi prioritas pembangunan nasional. Oleh karena itu, diperlukan sinergi kebijakan perencanaan di tingkat nasional dan tingkat provinsi maupun kabupaten/ kota. Di tingkat nasional, target-target MDGs telah diintegrasikan ke dalam Rencana Pembangunan Jangka Menengah Nasional (RPJMN) 2010-2014 dalam bentuk program, indikator maupun target yang terukur serta indikasi dukungan pembiayaannya (Bappenas, 2010).
Pelayanan kesehatan adalah hak asasi manusia, sebagaimana ditetapkan oleh Undang-Undang Dasar 1945 pasal $28 \mathrm{H}$. Oleh karenanya, pembangunan kesehatan diarahkan untuk meningkatkan kesadaran, kemauan, dan kemampuan hidup sehat bagi setiap orang agar terwujud derajat kesehatan masyarakat setinggi-tingginya. UndangUndang No. 17 Tahun 2007 tentang Rencana Pembangunan Jangka Panjang Nasional (RPJPN) menetapkan salah satu tujuan pembangunan yang ingin dicapai adalah mewujudkan daya saing bangsa. Untuk itu, pembangunan kesehatan merupakan komponen penting dalam pembangunan manusia demi menuju manusia Indonesia yang berdaya saing tinggi ini. Dalam pelaksanaannya, pembangunan jangka panjang dilakukan secara bertahap dalam pembangunan jangka menengah yang mengacu pada Rencana Pembangunan Jangka Menengah Nasional (Bappenas, 2009).

Secara umum, pencapaian sasaran pembangunan kesehatan masih kurang menggembirakan. Dalam RPJMN 20102014, sasaran pembangunan kesehatan adalah meningkatnya Umur Harapan Hidup (UHH), menurunnya Angka Kematian Ibu (AKI) melahirkan, menurunnya Angka Kematian Bayi (AKB), menurunnya prevalensi kekurangan gizi pada anak balita, dan menurunnya angka kelahiran total (Total Fertility Rate/TFR). Hingga tahun 2012, seluruh capaian indikator pembangunan kesehatan diperkirakan memerlukan upaya keras atau dengan kata lain, tidak dapat memenuhi target yang ditetapkan dalam RPJMN 2010-2014. Dengan demikian, dapat dikatakan bahwa sasaran pembangunan kesehatan masih memerlukan kerja keras untuk mencapai target yang ditetapkan.

Bappenas melansir hasil perkiraan capaian 14 Prioritas Nasional (PN) termasuk PN 3 kesehatan yang sebagian besar pembuktian pencapaiannya menggunakan data hasil Survei Demografi Kesehatan Indonesia 2012 
dan Sensus Penduduk 2010. Hasil capaian PN kesehatan tersebut diukur melalui 12 indikator, yakni Usia Harapan Hidup (UHH), Angka Kematian Ibu (AKI), cakupan persalinan nakes, Angka Kematian Bayi (AKB), cakupan imunisasi dasar, prevalensi kekurangan gizi, persentase timbang balita, Total Fertility Rate (TFR), prevalensi tuberkulosis, prevalensi kasus HIV, Annual Parasite Index (API), dan persentase jangkauan akses sumber air bersih (Bappenas, 2013). Sementara itu, Riset Kesehatan Dasar (Riskesdas) merupakan survei kesehatan secara nasional yang menyediakan data-data khusus kesehatan secara lengkap. Termasuk data kesehatan ibu dan anak guna menghitung indikator Total Fertility Rate (TFR) yang nantinya dapat melengkapi membuktikan indikator dalam Prioritas Nasional nomor 3 dalam RPJMN 2010-2014.

TFR merupakan ukuran estimasi kelahiran. Estimasi fertilitas dapat dilakukan menggunakan metode langsung dan tidak langsung. Penghitungan dengan metode langsung dapat digunakan jika didukung beberapa hal. Dua di antaranya adalah sistem registrasi vital yang ada dapat menghasilkan data statistik vital yang akurat dan jika survei atau sensus yang diadakan dapat menghasilkan data kelahiran yang dapat langsung digunakan untuk mengestimasi angka fertilitas. Sayangnya, sistem registrasi vital yang ada di Indonesia belum begitu baik sehingga statistik vital yang valid dan reliabel tidak dapat dihasilkan.

Sementara itu, penghitungan fertilitas dengan cara tidak langsung (indirect estimation), antara lain, menggunakan metode anak kandung. Metode ini memiliki beberapa keunggulan, seperti perkiraan angka kelahiran (Age Specific Fertility RateASFR) dapat dirinci menurut umur tahunan dan tidak memerlukan banyak informasi/ data. Informasi pokok yang diperlukan adalah jumlah anak yang tinggal bersama ibunya menurut umur. Namun, metode ini juga mempunyai beberapa kelemahan, seperti kealpaan/lupa jumlah anak, kesalahan pelaporan umur, dan kelebihan/kekurangan pencatatan anak maupun ibunya. Selain itu, mortalitas terutama mortalitas anak dapat memengaruhi hasil perkiraan fertilitas. Oleh karenanya, metode anak kandung digunakan dengan penyesuaian (adjusted) untuk menutupi kelemahan-kelemahan yang ada.

Perhitungan dengan metode ini menggunakan sumber data survei nasional belum banyak dilakukan. Data Survei Demografi dan Kesehatan Indonesia (SDKI) tahun 2012 melakukan penghitungan TFR, tetapi menggunakan metode estimasi langsung dengan angka TFR yang dihasilkan sebesar 2,6. Perhitungan dengan metode yang sama pernah dilakukan untuk Data Susenas 2010 dengan TFR sebesar 2,3 untuk nasional (BKKBN, 2013). Belum banyaknya penghitungan berbasis data survei nasional untuk menghitung angka TFR dengan metode tidak langsung menjadi alasan tulisan ini disusun.

\section{Metode}

Penelitian ini menggunakan data survei kesehatan, yakni data Riset Kesehatan Dasar (Riskesdas) tahun 2013. Riskesdas adalah sebuah survei dengan desain cross sectional. Riskesdas 2013 dimaksudkan untuk menggambarkan masalah kesehatan penduduk di seluruh pelosok Indonesia, yang terwakili oleh penduduk di tingkat nasional, provinsi, dan kabupaten/kota (Balitbangkes, 2013). Karena menggunakan data survei, maka perhitungan TFR dilakukan dengan metode penghitungan secara tidak langsung.

Populasi dalam Riskesdas 2013 adalah seluruh rumah tangga biasa yang mewakili 33 provinsi. Sampel rumah tangga dalam Riskesdas 2013 dipilih berdasarkan listing Sensus Penduduk (SP) 2010. Sementara itu, proses pemilihan rumah tangga ditentukan oleh BPS yang memberikan daftar bangunan 
sensus terpilih yang berasal dari Blok Sensus (BS) terpilih. Dari 12.000 BS terpilih untuk sampel Riskesdas 2013, berhasil ditemukan dan dikunjungi 11.986 BS (99,9 persen) yang tersebar di 33 provinsi dan 497 kabupaten/ kota. Adapun jumlah rumah tangganya adalah 294.959 dari 300.000 RT yang ditargetkan (98,3 persen) dengan jumlah anggota rumah tangga (ART) 1.027 .763 orang (93 persen). Namun, 14 BS dengan rincian 12 BS di Papua, 1 BS di Papua Barat, dan 1 BS di DKI Jakarta tidak berhasil dikunjungi karena sulit dijangkau dan ada penolakan warga setempat.

Populasi dalam penelitian ini adalah semua perempuan dan anak-anak yang tinggal bersama orang tuanya. Kemudian sampel dalam analisis perhitungan ini adalah wanita usia subur (WUS) umur 15 hingga 49 tahun dan anak balita yang tinggal bersama orang tuanya. Anak-anak balita dalam perhitungan ini adalah anak kandung, sedangkan anak dengan status bukan anak kandung dilibatkan dalam perhitungan guna menambah jumlah anak yang berada dalam rumah tangga ibu.

Data perempuan dan balita didapat dari daftar seluruh individu yang tinggal dalam satu rumah tangga. Data set perempuan usia subur dibuat berdasarkan variabel hubungan dengan Kepala Rumah Tangga (KRT) berkode 1 atau 2 dan berjenis kelamin perempuan yang berumur 15-49 tahun. Data anak dibuat berdasarkan variabel hubungan dengan KRT berkode 3 (anak kandung) dan 4 (anak angkat/tiri) yang berumur 0-59 bulan.

Perhitungan akan dilakukan dengan data set perempuan dan anak berumur di bawah 15 tahun sehingga dihasilkan beberapa indikator fertilitas. Untuk melakukan perhitungan fertilitas data survei, digunakan metode estimasi tidak langsung (indirect estimation). Estimasi tidak langsung ini banyak digunakan di berbagai negara yang belum melaksanakan pencatatan registrasi kelahiran dan kematian pada penduduknya.
Perhitungan estimasi tidak langsung menggunakan metode anak kandung digunakan untuk ukuran fertilitas pada data Susenas di tingkat nasional hingga kabupaten (BKKBN, 2013). Sementara itu, analisis data Survei Demografi Kesehatan Indonesia juga menggunakan perhitungan estimasi tidak langsung meskipun tidak dijelaskan metode perhitungan yang digunakannya (BPS, 20022007). Untuk perhitungan TFR dalam analisis ini, digunakan metode anak kandung atau dikenal dengan own children method (OCM), yang merupakan perbaikan metode reverse survival ratio. Keunggulan dari OCM adalah perkiraan angka kelahiran (ASFR) dapat dirinci menurut umur tahunan dan tidak memerlukan banyak informasi/data. Informasi pokok yang diperlukan adalah jumlah anak yang tinggal bersama ibunya menurut kelompok umur ibunya (BPS, 2012). Estimasi perhitungan dengan memperkirakan angka fertilitas sebelum survei dilakukan atas dasar tabulasi dari anak-anak yang tinggal bersama ibunya saat pencacahan atau pendataan dilakukan.

\section{Hasil}

\section{A. Karakteristik}

Distribusi hasil analisis data sampel jika dilihat berdasarkan umur, jenis kelamin, dan status perkawinan dapat dilihat pada Tabel 1. Berdasarkan Tabel 1, jumlah laki-laki yang belum kawin tidak berbeda jauh dengan lakilaki yang kawin atau pernah kawin. Sementara itu, pada perempuan, jumlah yang pernah kawin lebih besar dibandingkan dengan perempuan belum kawin. Yang menarik pada penduduk laki-laki umur 5-14 tahun adalah jumlah yang telah kawin sebesar 22,8 persen serta pada perempuan di kelompok umur yang sama dan telah kawin berjumlah 20 persen. Untuk lebih lengkapnya, dapat dilihat pada Tabel 1. 
Tabel 1 Distribusi Penduduk menurut Umur, Jenis Kelamin, dan Status Perkawinan, Riskesdas 2013

\begin{tabular}{lrr|rr|rr}
\hline & \multicolumn{2}{c}{ Belum Kawin } & \multicolumn{2}{c}{ Kawin } & \multicolumn{2}{c}{ Total } \\
\cline { 2 - 6 } & \multicolumn{1}{c}{$\mathbf{n}$} & \multicolumn{1}{c}{$\%$} & $\mathbf{n}$ & $\mathbf{0}$ & \% \\
\hline Laki-laki & & & & & & \\
0-4 Tahun & 42.227 & 16,7 & 0 & 0,0 & 42.227 & 8,4 \\
5-14 Tahun & 114.625 & 45,3 & 734 & 0,3 & 115.359 & 22,8 \\
15-49 Tahun & 95.325 & 37,6 & 154.789 & 61,4 & 250.114 & 49,5 \\
50+ Tahun & 1.034 & 0,4 & 96.675 & 38,3 & 97.709 & 19,3 \\
Total Laki-laki & 253.211 & 100 & 252.198 & 100 & 505.409 & 100 \\
\hline Perempuan & & & & & & \\
0-4 Tahun & 40.439 & 18,5 & 0 & 0,0 & 40.439 & 7,7 \\
5-14 Tahun & 107.298 & 49,2 & 111 & 0,0 & 107.409 & 20,6 \\
15-49 Tahun & 68.640 & 31,5 & 203.916 & 67 & 272.556 & 52,2 \\
50+ Tahun & 1.736 & 0,8 & 100.214 & 32,9 & 101.950 & 19,5 \\
Total Perempuan & 218.113 & 100 & 304.241 & 100 & 522.354 & 100 \\
$\boldsymbol{\Sigma}$ laki \& perempuan & 471.324 & 100 & 556.439 & 100 & 1.027 .763 & 100 \\
\hline
\end{tabular}

Sumber: Riset Kesehatan Dasar 2013, diolah

Anak kandung didapat dari keterangan Anggota Rumah Tangga (ART), yakni variabel B4K3 yang berkode 3. Pada subset anak balita, awalnya dilakukan pengecekan umur untuk melihat umur bulan anak tidak melebihi 59 bulan. Kemudian data set anak digabung (merged) dengan data ibu agar didapatkan jumlah anak balita kandung di setiap kategori umur ibu. Untuk penyesuaian jumlah anak, dihitung juga jumlah anak bukan kandung yang ada di rumah tangga ibu pada setiap kategori umur ibu. Tabel 2 menunjukkan gabungan anak balita dan ibu.

Tabel 2 Jumlah Anak Balita dan Jumlah Perempuan berdasarkan Kategori Umur Ibu, Riskesdas 2013

\begin{tabular}{lrr|rr}
\hline \multirow{2}{*}{$\begin{array}{l}\text { Umur Ibu } \\
\text { (Tahun) }\end{array}$} & \multicolumn{2}{c|}{ Anak di Tahun 2013 } & \multicolumn{2}{c}{ Perempuan di Tahun 2013 } \\
\cline { 2 - 5 } & Jumlah & \% & Jumlah & \% \\
\hline $15-19$ & 684 & 1,0 & 1.353 & 0,7 \\
$20-24$ & 7.031 & 10,3 & 9.172 & 5,0 \\
$25-29$ & 16.928 & 24,7 & 24.040 & 13,0 \\
$30-34$ & 20.877 & 30,4 & 36.711 & 19,8 \\
$35-39$ & 14.721 & 21,5 & 39.485 & 21,3 \\
$40-44$ & 6.922 & 10,1 & 39.785 & 21,5 \\
$45-49$ & 1,429 & 2,1 & 34.694 & 18,7 \\
\hline Total Anak & $\mathbf{6 8 . 5 9 2}$ & $\mathbf{1 0 0}$ & $\mathbf{1 8 5 . 2 4 0}$ & $\mathbf{1 0 0}$ \\
\hline
\end{tabular}

Sumber: Riset Kesehatan Dasar 2013, diolah 
Tabel 3 Umur Riwayat Fertilitas Wanita Usia Subur, Riskesdas 2013

\begin{tabular}{lcc}
\hline Umur (tahun) & $\begin{array}{c}\text { Pertama Kali Menikah/Hidup } \\
\text { Bersama (\%) }\end{array}$ & Pertama Kali Hamil (\%) \\
\hline$<15$ & 3,3 & $\mathbf{1 , 5}$ \\
$15-19$ & 40,1 & 33,1 \\
$20-24$ & 39,8 & 45,0 \\
$25-29$ & 13,9 & 16,4 \\
$30-34$ & 2,2 & 3,1 \\
$35-39$ & 0,4 & 0,6 \\
$40-44$ & 0,0 & 0,1 \\
$45-49$ & 0,0 & 0,0 \\
$>50$ & 0,2 & 0,2 \\
\hline
\end{tabular}

Sumber: Riset Kesehatan Dasar 2013, diolah

Berdasarkan Tabel 2, jumlah anak balita terbanyak ada pada kelompok umur ibu berusia 30-34 tahun, yakni 20.877 anak atau 30,4 persen. Pada kelompok perempuan umur 25-29 tahun, jumlah anak sebesar 16.928 anak atau 24,7 persen. Kemudian untuk jumlah perempuan terbanyak, ada pada kelompok umur 40-44 tahun, yakni 39.785 orang atau 21,5 persen.

Dari keseluruhan WUS tersebut yang telah dikelompokkan, dapat diketahui riwayat fertilitasnya secara lebih mendalam, yakni mengenai umur ketika menikah atau hidup bersama pertama kali (variabel lb01) dan umur ketika pertama kali hamil (variabel lb06).
Pada Tabel 3 umur pertama kali menikah pada WUS terbanyak adalah pada rentang 15-19 tahun sebanyak 40,1 persen. Kemudian diikuti pada rentang umur 20-24 tahun, yakni sebesar 39,8 persen. Sementara itu, WUS 1549 tahun memiliki riwayat pertama kali hamil pada usia 20-24 tahun dengan persentase 45 persen yang diikuti rentang 15-19 tahun sebesar 33,1 persen. Semakin muda umur WUS menikah dan hamil akan berpengaruh potensi/risiko melahirkan/memiliki anak. Hal ini berarti bahwa semakin muda seorang perempuan menikah/hamil akan semakin besar potensi melahirkan dan memiliki anak jika tidak dicegah. Hal ini tergambar dalam Tabel 4 dan 5 berikut ini.

Tabel 4 Hubungan antara Umur WUS Pertama Kali Menikah dan Jumlah Anak, Riskesdas 2013

\begin{tabular}{lcc}
\hline $\begin{array}{l}\text { Umur saat Menikah/Hidup } \\
\text { Bersama Pertama Kali }\end{array}$ & Frekuensi $\mathbf{( N = 6 8 . 5 9 2 )}$ & Persentase \\
\hline$<15$ tahun & 1.821 & 2,7 \\
$15-19$ tahun & 25.659 & 37,4 \\
$20-24$ tahun & 28.080 & 40,9 \\
$25-29$ tahun & 10.699 & 15,6 \\
$30-34$ tahun & 1.791 & 2,6 \\
$35-39$ tahun & 382 & 0,6 \\
$40-44$ tahun & 28 & 0,0 \\
$45-49$ tahun & 0 & 0 \\
$>50$ tahun & 132 & 0,2 \\
\hline
\end{tabular}

Sumber: Riset Kesehatan Dasar 2013, diolah 
Tabel 5 Hubungan antara Umur Hamil Pertama Kali dan Jumlah Anak, Riskesdas 2013

\begin{tabular}{|c|c|c|}
\hline $\begin{array}{l}\text { Umur saat Hamil Pertama Kali } \\
\text { (tahun) }\end{array}$ & Frekuensi & Persentase \\
\hline$<15$ & 780 & 1,1 \\
\hline $15-19$ & 20.848 & 30,7 \\
\hline $20-24$ & 30.741 & 45,2 \\
\hline $25-29$ & 12.361 & 18,2 \\
\hline $30-34$ & 2.439 & 3,6 \\
\hline $35-39$ & 567 & 0,8 \\
\hline $40-44$ & 74 & 0,1 \\
\hline $45-49$ & 5 & 0,0 \\
\hline$>50$ & 121 & 0,2 \\
\hline Total & 67.936 & 100 \\
\hline
\end{tabular}

Sumber: Riset Kesehatan Dasar 2013, diolah

Pada Tabel 5 terlihat bahwa umur saat menikah/hidup bersama pertama kali terbanyak ada pada kelompok umur $<19$ tahun dan 20-24 atau umur muda, yakni masingmasing 40,1 persen dan 40,9 persen. Angka yang lebih rendah berada pada kelompok umur 25-29 tahun sebesar 15,6 persen.

\section{B. Hasil Penghitungan TFR Nasional}

Perhitungan Total Fertility Rate (TFR) dan Age Specific Fertility Rate (ASFR) secara nasional dilakukan menggunakan metode anak kandung (OCM) dasar yang telah disesuaikan (adjusted). Metode perhitungan fertilitas ini merupakan salah satu metode estimasi secara tidak langsung. Yang dimaksudkan dengan TFR adalah jumlah rata-rata anak yang akan dilahirkan oleh seorang perempuan pada akhir masa reproduksinya apabila perempuan tersebut mengikuti pola fertilitas saat TFR dihitung (Kasto, 1995). TFR menyatakan fertilitas pada akhir masa reproduksi dari suatu kohor hipotesis perempuan. TFR dihitung dengan cara menjumlahkan angka kelahiran menurut umur (ASFR) dikalikan dengan interval kelompok umur (biasanya lima tahun).
Sementara itu, metode anak kandung atau lebih dikenal dengan Own Children diperkenalkan pertama kali oleh W.H. Grabill yang kemudian diperbaiki bersama Lee Jay Cho pada awal 1960-an. Dasar asumsi perkiraan fertilitas ini menggunakan metode survival ratio yanga memperkirakan angka fertilitas sebelum sensus atau survei kependudukan dilakukan atas dasar tabulasi dari anak-anak yang tinggal bersama ibunya saat pencacahan atau pendataan dilakukan.

Tahapan perhitungan TFR menggunakan data yang merupakan hasil survei dilakukan pembobotan nilai sampel terhadap jumlah penduduk guna melihat jumlah data pada populasi penduduk yang sebenarnya. Dengan demikian, perhitungan TFR ini mampu menggambarkan keadaan yang sebenarnya di masyarakat secara statistik. Berikut ini adalah tahapan ketika menghitung TFR yang telah dijustifikasi dengan total jumlah anak. Pertama, pada subset data gabungan antara WUS 15-49 tahun dengan anak balita dilakukan analisis frekuensi jumlah anak kandung berdasarkan umur ibu yang telah dikategorisasi dengan melakukan inflate jumlah anak sebelumnya. Perhitungan yang sama dilakukan untuk mendapat jumlah anak bukan kandung. Kemudian dua perhitungan tersebut dijumlahkan untuk mendapatkan total 
Tabel 6 Perhitungan Jumlah Penduduk Anak dan Jumlah Penduduk Perempuan, Riskesdas 2013

\begin{tabular}{lrrrr}
\hline $\begin{array}{l}\text { Umur Ibu } \\
\text { (thn) }\end{array}$ & $\begin{array}{c}\text { Anak } \\
\text { Kandung } \\
\text { (kolom 1) }\end{array}$ & $\begin{array}{c}\text { Anak Bukan } \\
\text { Kandung } \\
\text { (kolom 2) }\end{array}$ & $\begin{array}{c}\text { Total Anak } \\
\text { (kolom 3) }\end{array}$ & $\begin{array}{c}\text { Penduduk } \\
\text { Perempuan } \\
\text { (kolom 4) }\end{array}$ \\
\hline $15-19$ & 218.280 & 1.119 & 219.399 & 415.932 \\
$20-24$ & 2.628 .506 & 4.741 & 2.633 .247 & 3.516 .676 \\
$25-29$ & 5.815 .585 & 9.154 & 5.824 .739 & 8.582 .453 \\
$30-34$ & 4.929 .438 & 3.409 & 4.932 .847 & 8.790 .850 \\
$35-39$ & 3.476 .157 & 5.405 & 3.481 .607 & 9.465 .323 \\
$40-44$ & 1.344 .621 & 3.503 & 1.348 .124 & 8.122 .411 \\
$45-49$ & 274.705 & 1.416 & 276.121 & 7.213 .274 \\
Jumlah & 18.687 .292 & 28.792 & 18.716 .084 & 46.106 .919 \\
\hline
\end{tabular}

Sumber: Riset Kesehatan Dasar 2013, diolah

jumlah anak di setiap kategori umur ibu. Untuk mendapatkan jumlah penduduk perempuan di tahun survei, dilakukan analisis frekuensi per kategori umur ibu dengan melakukan inflate jumlah ibu sebelumnya. Hasil perhitungan tahap pertama dapat dilihat pada Tabel 6 .

Tahap perhitungan selanjutnya adalah melakukan estimasi/perkiraan jumlah penduduk perempuan dan jumlah anak balita pada lima tahun sebelum survei menggunakan pola life tableyang tersedia. Untukmenetapkan level of mortality pada life table, digunakan patokan umur harapan hidup pada waktu lahir
(UHH/life expectacion at birth) tahun 20102011, yakni 71-72 (Tim, 2011). Perhitungan jumlah penduduk perempuan WUS 15-49 tahun pada 2008 dilakukan berdasarkan tabel Five Years Life Tables Survival Ratio General Pattern-Female (BPS, 2011). Berdasarkan tabel tersebut, didapat survival rate di setiap kategori umurnya. Sebagai contoh, pada kelompok umur perempuan 15-19 tahun, angka survival rate di UHH 71 dan 72 adalah 0,9974 dan 0,9977. Kemudian berdasarkan angka tersebut, diperoleh rata-rata survival rate perempuan umur 15-19 tahun dengan

Tabel 7 Hasil Estimasi Jumlah Balita dan Perempuan di Indonesia

\begin{tabular}{|c|c|c|c|c|c|}
\hline $\begin{array}{c}\text { Umur Ibu } \\
\text { (tahun) }\end{array}$ & $\begin{array}{l}\text { Total Anak } \\
\text { (kolom 3) }\end{array}$ & $\begin{array}{c}\text { Perempuan } \\
\text { di Thn } 2013 \\
\text { (kolom 4) } \\
\end{array}$ & $\begin{array}{c}\text { Survival } \\
\text { Rate } \\
\text { Perempuan } \\
\text { (kolom 5) } \\
\end{array}$ & $\begin{array}{l}\text { Kelahiran } \\
\text { 2008-2013 } \\
\text { (kolom 6) } \\
\end{array}$ & $\begin{array}{c}\text { Estimasi } \\
\text { Perempuan } \\
\text { Thn } 2008 \\
\text { (kolom 7) } \\
\end{array}$ \\
\hline $15-19$ & 219.399 & 415.932 & 0,99755 & 229.030 & 416.954 \\
\hline $20-24$ & 2.633 .247 & 3.516 .676 & 0,99655 & 2.748 .836 & 3.528 .851 \\
\hline $25-29$ & 5.824 .739 & 8.582 .453 & 0,9954 & 6.080 .421 & 8.622 .115 \\
\hline $30-34$ & 4.932 .847 & 8.790 .850 & 0,9941 & 5.149 .378 & 8.843 .024 \\
\hline $35-39$ & 3.481 .607 & 9.465 .323 & 0,99215 & 3.634 .435 & 9.540 .214 \\
\hline $40-44$ & 1.348 .124 & 8.122 .411 & 0,98905 & 1.407 .301 & 8.212 .336 \\
\hline $45-49$ & 276.121 & 7.213 .274 & 0,98415 & 288.242 & 7.329 .446 \\
\hline Jumlah & 18.716.084 & 46.106 .919 & & 19.537.642 & 46.492 .938 \\
\hline
\end{tabular}

Sumber: Riset Kesehatan Dasar 2013, diolah 
PERHITUNGAN FERTILITAS MENGGUNAKAN METODE ANAK KANDUNG:

ANALISIS LANJUT DATA RISKESDAS 2013

Tabel 8 Estimasi Angka Fertlitas Metode Anak Kandung di Indonesia

\begin{tabular}{cccc}
\hline Umur lbu & $\begin{array}{c}\text { Penduduk } \\
\text { Perempuan 2008- } \\
\text { 2013 }\end{array}$ & $\begin{array}{c}\text { Kelahiran per 1.000 } \\
\text { perempuan } \\
\text { (kolom 8) }\end{array}$ & ASFR \\
\hline $15-19$ & 416.443 & 550,0 & (kolom 10) \\
\hline $20-24$ & 3.522 .763 & 780,3 & 149 \\
$25-29$ & 8.602 .284 & 706,8 & 195 \\
$30-34$ & 8.816 .937 & 584,0 & 130 \\
$35-39$ & 9.502 .768 & 382,5 & 99 \\
$40-44$ & 8.167 .374 & 172,3 & 54 \\
$45-49$ & 7.271 .360 & 39,6 & 18 \\
\hline
\end{tabular}

Sumber : Riset Kesehatan Dasar 2013, diolah

perhitungan $(0,9974+0,9977): 2=0,99755$. Jumlah penduduk perempuan tahun 2008 dihitung dengan membagi jumlah penduduk perempuan tahun 2013 dengan hasil perhitungan angka survival rate tersebut.

Estimasi jumlah kelahiran balita untuk periode lima tahun (2008-2013) juga dihitung berdasarkan life table, yakni survival rate untuk bayi yang dapat bertahan sampai empat tahun. Pada Tabel 7 tertera survival rate pada bayi sejak lahir hingga empat tahun dengan UHH 71 dan 72 adalah 0,9562 dan 0,9597 . Perkiraan jumlah balita dilakukan dengan membagi jumlah anak balita tahun 2013 dengan survival rate masing-masing. Perhitungan estimasi tersebut dapat dilihat pada Tabel 7.

Berdasarkan data jumlah penduduk perempuan tahun 2013 (hasil survei, kolom 4) dan jumlah estimasi penduduk perempuan tahun 2008 (kolom 7), maka dapat diperoleh jumlah penduduk perempuan pertengahan tahun 2008-2013. Hal itu dilakukan dengan menambahkan kolom 4 dan kolom 7 kemudian dibagi dua. Langkah selanjutnya adalah menghitung jumlah kelahiran per 1.000 perempuan dengan membagi jumlah kelahiran selama tahun 2008-2013 terhadap jumlah penduduk perempuan di periode tahun yang sama dikalikan seribu pada setiap kategori umur ibu.
Angka fertilitas menurut umur (ASFR) diperkirakan dengan cara membagi jumlah kelahiran selama periode 2008-2013 dengan jumlah penduduk perempuan pada pertengahan 2008-2013. Namun, angka fertilitas per 1.000 penduduk perempuan menurut umur yang dihasilkan ini hanya menunjuk pada tengah umur, yakni 17,5; 22,$5 ; 27,5 ; 32,5 ; 37,5 ; 42,5$; dan 47,5 tahun. Oleh karenanya, diperlukan distribusi angka fertilitas menurut umur yang konvensional, yakni 15-19; 20-24; 25-29; 30-34; 35-39; 4044; dan 45-49 tahun. Distribusi angka fertilitas yang konvensional ini dapat diperoleh menggunakan formula Spraque Multiplier (UN, 1982). Hasil perhitungan tercantum pada kolom 10 Tabel 8.

Berdasarkan Tabel 8, maka dapat diperoleh ukuran TFR dengan menjumlahkan angka fertilitas menurut umur yang dikalikan lima. Hasilnya adalah 3.235 per 1.000 perempuan atau 3,2 per perempuan. Dengan kata lain, setiap perempuan pada masa usia suburnya rata-rata melahirkan tiga anak.

Angka fertilitas menurut umur (ASFR) merupakan gambaran banyaknya kelahiran perempuan suatu kelompok umur pada suatu tahun tertentu per 1.000 perempuan di pertengahan tahun yang sama. Jumlah kelahiran terbanyak ada pada ibu di kelompok umur 20-24 tahun, yakni 195 anak. Terbanyak kedua diikuti pada kelompok umur 15- 
19 tahun sebesar 149 anak. Hal ini cukup mengejutkan mengingat kelompok umur 1519 tahun merupakan kelompok umur masih muda untuk melahirkan.

\section{Pembahasan}

Hasil perhitungan TFR nasional di Indonesia berdasarkan Riskesdas 2013 adalah 3,2. Hal ini berarti setiap perempuan usia subur rata-rata melahirkan tiga anak (pembulatan ke bawah) sampai dengan akhir masa reproduksinya. Angka ini terlihat lebih tinggi jika dibandingkan dengan data SDKI (Survei Demografi Kesehatan Indonesia) tahun 2012 yang menghitung angka TFR sebesar 2,6 (CI SE : 2,5-2,7) (Iskandar, 1977). Terlepas dari persoalan perbedaan sumber data, hasil perhitungan ini menunjukkan bahwa TFR Indonesia masih tinggi. Jika angka ini digunakan patokan, akan sangat sulit untuk mencapai TFR 2,1 pada 2015 seperti yang dimandatkan oleh RPJMN.

Sementara itu, metode penghitungan angka TFR yang digunakan dalam SDKI dan perhitungan analis/tulisan ini memiliki perbedaan. Perhitungan menggunakan sumber data SDKI dilakukan dengan teknik perhitungan secara langsung (direct method). Sementara itu, perhitungan pada tulisan ini yang memanfaatkan data Riskesdas menggunakan teknik perhitungan tidak langsung (indirect method), khususnya metode anak kandung yang telah disesuaikan atau own-children method (adjusted).

Kemungkinan lain adanya perbedaan angka TFR yang dihasilkan oleh SDKI adalah karena perbedaan estimasi sampel yang digunakan. Sampel Riskesdas bertujuan melakukan estimasi terhadap masalah kesehatan di tingkat kabupaten/kota, provinsi, dan nasional. Sementara itu, SDKI melakukan estimasi karakteristik penting dari WUS 15-49 tahun dan pria kawin 15-54 tahun di tingkat provinsi dan nasional di setiap daerah perkotaan dan perdesaan. Dengan demikian, sampel SDKI lebih banyak untuk mengestimasi WUS sehingga kemungkinan hasil generalisasi lebih presisi. Selanjutnya penghitungan TFR pada SDKI menggunakan metode full birth history (FBH), sedangkan untuk data Riskesdas ini, TFR dihitung menggunakan Own-children method (OCM).

Secara umum, penggunaan teknik penghitungan OCM lebih akurat dibandingkan dengan menggunakan $\mathrm{FBH}$ (Christopher, 2013). Setidaknya ada beberapa hal yang menyebabkan metode penghitungan OCM lebih akurat, misalnya karena metode penghitungan $\mathrm{FBH}$ cenderung inkonsistensi dalam melakukan pengodean umur. Hal ini menyebabkan perbedaan estimasi terlalu besar ketika menggunakan $\mathrm{FBH}$. Hal lainnya adalah terdapat bias seleksi yang cukup besar ketika menghitung anak dalam metode $\mathrm{FBH}$. Oleh karenanya, secara keseluruhan, penghitungan TFR dipengaruhi dengan asumsi kematian anak, yaitu jika salah menghitung umur anak, maka itu akan memengaruhi kesalahan dalam pencocokkan kepada ibunya. Kesalahan ini makin besar pada penggunaan metode $\mathrm{FBH}$. Hal lainnya yang memengaruhi perbedaan angka TFR Riskesdas dengan SDKI lainnya adalah fertilitas di SDKI dihitung untuk periode tiga tahun terakhir sebelum data diambil dan dihitung secara langsung dari data riwayat kelahiran. Dengan demikian, anak yang dihitung adalah anak berumur di bawah 3 tahun. Sementara itu, fertilitas di Riskesdas untuk perhitungan TFR ini dihitung berdasarkan jumlah anak yang berumur kurang dari 5 tahun yang dikelompokkan berdasarkan kelompok umur ibunya.

Perhitungan TFR lainnya yang menggunakan metode sama dilakukan pada data Susenas 2010, yakni metode perhitungan tidak langsung anak kandung (BKKBN, 2013). Hanya secara waktu, Susenas 2010 menghitung fertilitas 5 tahun ke belakang (2005-2010), sedangkan data fertilitas Riskesdas 2013 dihitung mulai tahun 


\section{PERHITUNGAN FERTILITAS MENGGUNAKAN METODE ANAK KANDUNG: ANALISIS LANJUT DATA RISKESDAS 2013}

2008 hingga 2013. Hasil perhitungan TFR menggunakan Susenas tahun 2010 adalah sebesar 2,3.

Hasil perhitungan fertilitas di setiap kelompok umur perempuan (ASFR) terlihat linier berkurang dengan bertambahnya umur, kecuali pada kelompok 20-24 tahun (lihat Tabel 8). Hal ini terjadi, salah satunya, karena umur menikah/hidup bersama terbanyak berada di umur WUS masih muda, yaitu rentang umur $<19$ tahun dan 20-24 tahun (lihat Tabel 7). Ini berarti ketika seorang perempuan menikah/ hidup bersama pertama kali pada umur belia, rentang waktu reproduksinya lebih panjang jika tidak diatur/dibatasi. Jika tidak dilakukan pengaturan kehamilan, maka potensi/risiko memiliki total anak yang dilahirkan akan semakin banyak (Tabel 8).

Pola ini agak berbeda dengan pola data SDKI 2012 karena jumlah kelahiran terbesar ada pada kelompok umur 25-29 tahun. Jumlah kelahiran terbanyak per 1.000 perempuan di kelompok umur 25-29 juga muncul pada perhitungan ASFR menggunakan data Susenas 2010. Untuk lebih jelasnya, perbandingan jumlah kelahiran di setiap kelompok pada hasil perhitungan data Riskesdas 2013, SDKI 2012, dan Susenas 2010 terdapat pada Grafik 1 berikut ini.

Perbandingan di setiap kelompok umur (Grafik 1), Jumlah kelahiran spesifik pada kelompok umur perempuan 15-19 tahun dan 20-24 tahun berdasarkan Riskesdas (RKD) 2013 paling tinggi dibandingkan dengan jumlah kelahiran SDKI 2012 dan Susenas 2010 di kelompok umur yang sama. Ini terjadi karena pernikahan/hidup bersama pada usia muda semakin meningkat jumlahnya. Pada kelompok umur 25-29 tahun, hitungan data SDKI sedikit lebih besar dibandingkan dengan data lainnya. Sementara itu, hitungan ASFR menggunakan data Susenas 2010 sedikit

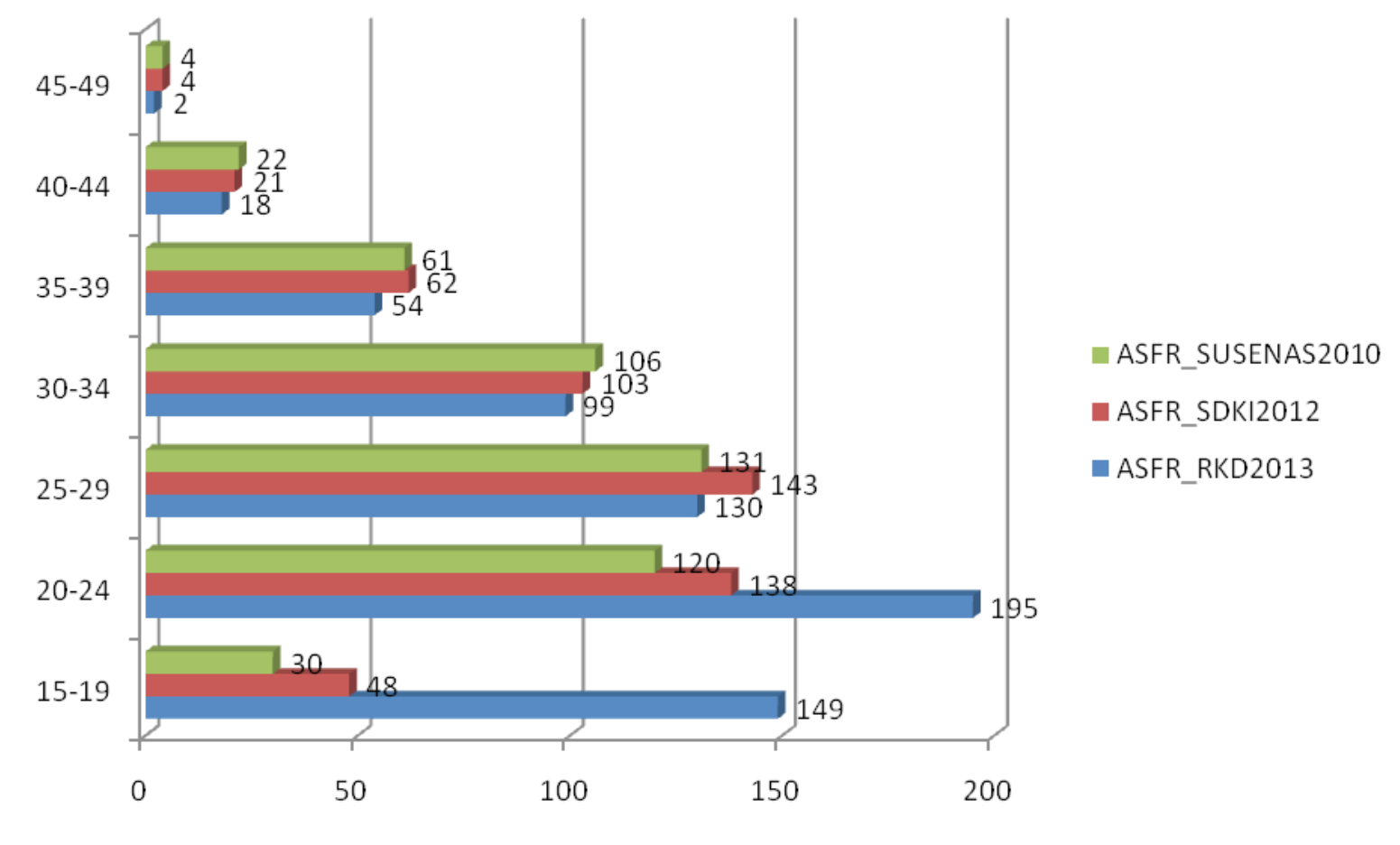

Sumber: Riset Kesehatan Dasar 2013, diolah

Grafik 1 Perbandingan Hitungan Age Specific Fertilitas Rate (ASFR) antara data Riskesdas 2013, SDKI 2012 dan Susenas 2010 
lebih besar jika dibandingkan dengan pada kelompok umur ibu usia 30-34 tahun, 35-39 tahun, dan 40-44 tahun.

\section{Kesimpulan}

Hasil perhitungan TFR di Indonesia adalah 3.235 per 1.000 perempuan atau 3,2 per perempuan. Dengan kata lain, setiap perempuan pada masa usia suburnya ratarata melahirkan tiga anak. Metode yang digunakan untuk mendapatkan perhitungan ini menggunakan metode anak kandung (own children method) dengan dasar yang telah disesuaikan (adjusted). Hasil hitungan TFR 3,2 menandakan Prioritas Nasional nomor 3 untuk indikator penurunan TFR tahun 2014 sebesar 2,1 masih jauh di bawah target.

Hasil perhitungan fertilitas di setiap kelompok umur perempuan (ASFR) terlihat bahwa kelompok umur perempuan 2024 tahun memiliki potensi terbanyak melahirkan anak, yaitu 195 kelahiran per 1.000 perempuan. Kemudian diikuti oleh kelompok umur lebih muda, yakni 15-19 tahun, dengan 149 kelahiran per 1.000 perempuan dibandingkan dengan kelompok umur yang lebih tua (di atas 24 tahun). Ini berarti perempuan muda umur 15-19 tahun telah menikah atau berhubungan badan sebelum rentang umur tersebut. Jika seorang perempuan telah menikah dalam umur belia, maka potensi/risiko untuk memiliki anak lebih besar jika tanpa pembatasan kelahiran.

\section{Saran}

Berdasarkan perhitungan, TFR di Indonesia tahun 2008-2013 sebesar 3,2. Ini berarti program pembatasan jumlah anak yang diharapkan oleh pemerintah, yakni Dua Anak Lebih Baik dalam satu keluarga, rata-rata belum tercapai. Jika dibandingkan dengan hasil perhitungan yang lain, ada kecenderungan bahwa TFR Indonesia mengalami stagnasi. Jika pembatasan tidak digiatkan kembali, dikhawatirkan jumlah penduduk Indonesia akan semakin meningkat di tahun-tahun mendatang. Kelompok umur WUS sangat muda (di bawah 19 tahun) memerlukan perhatian yang lebih khusus dalam program kesehatan reproduksi terkait dengan pengaturan waktu kehamilan untuk menghindari risiko kesehatan dalam masa hamil dan melahirkan. Perlu dilakukan analisis lebih lanjut tentang hubungan umur menikah muda dengan jumlah anak yang dilahirkan serta dampak kesehatan anak yang dilahirkan.

\section{Ucapan Terima Kasih}

Analisis lanjut data Riskesdas 2013 untuk penghitungan Total Fertilitas Rate (TFR) menggunakan own-children method ini merupakan kerja sama tim penulis. Ucapan terima kasih juga disampaikan kepada Dr. dr. Trihono selaku 'teman' sekaligus pimpinan kami yang di tengah kesibukannya telah memberi saran dan masukan yang sangat berarti dalam analisis dan tulisan kami ini.

\section{Daftar Pustaka}

Badan Kependudukan Keluarga Berencana Nasional. 2013. Penyajian TFR Kabupaten dan Kota: Data Susenas 2010.

Badan Litbang Kesehatan, Kementerian Kesehatan RI. 2013. Laporan Riset Kesehatan Dasar (RISKESDAS) Tahun 2013.

Badan Perencanaan Pembangunan Nasional/ Kementerian Perencanaan Pembangunan Nasional. 2009. Pembangunan Kesehatan dan Gizi di Indonesia: Overview dan Arah ke Depan. 
-----. 2010. Pedoman Penyusunan Rencana Aksi Percepatan Pencapaian Tujuan MDGs di Daerah (RAD MDGs).

-----. 2013. Evaluasi Paruh Waktu RPJMN 2010-2014.

Badan Pusat Statistik dan ORC Macro. 2003. Survei Demografi dan Kesehatan Indonesia 2002-2003. Calverton, Maryland, USA: ORC Macro.

Badan Pusat Statistik dan Makro Internasional. 2007. Survei Demografi dan Kesehatan Indonesia 2007. Calverton, Maryland, USA: BPS dan Macro Internasional.

Badan Pusat Statistik. 2011. Indeks Pembangunan Manusia 2010-2011.

Badan Pusat Statistik dan ICF Internasional. 2013. Survei Demografi dan Kesehatan Indonesia 2012.

Christopher Avery, et.al. 2013. "The Own Children Fertility Estimation Procedure: A Reappraisal". Population Studies: A Journal of Demography, Vol. 67, Issue 2, Pp. 171-183.

Departemen Kesehatan Republik Indonesia. 2011. Buku Saku MDGs di bidang Kesehatan Tahun 2011-2015.

Kasto. 1995. "Hand Out Tehnik Demografi PND 111". Program Studi Kependudukan Fakultas Pasca Sarjana Universitas Gajah Mada, Yogyakarta.

Iskandar, N. 1977. Teknik Demografi. Jakarta: Lembaga Demografi, Fakultas Ekonomi, Universitas Indonesia.

Tim Penulis Lembaga Demografi UI, Oetomo SM \& Samosir. (eds.). 2011. Dasar-Dasar Demografi. Jakarta: Penernit Salemba Empat.

United Nations. 1982. Models Life Tables for Developing Countries. New York: Departement of International Economic and Social Affairs. 